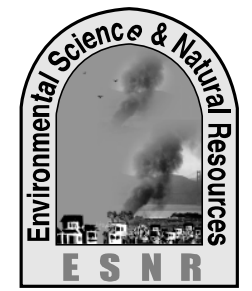

\title{
Analysis of Physicochemical Properties of the Turag River Water, Tongi, Gazipur in Bangladesh
}

\author{
M. N. Mobin, M. S. Islam, M. Y. Mia* and B. Bakali \\ Department of Environmental Science and Resource Management \\ Mawlana Bhashani Science and Technology University, Santosh, Tangail-1902 \\ *Corresponding author: oshin1998@yahoo.com
}

\begin{abstract}
The study deals with the assessment of water quality parameters including $\mathrm{pH}, \mathrm{DO}, \mathrm{BOD}$, temperature, TDS, EC, transparency, hardness, and alkalinity of the Turag River in Tongi, Gazipur, Bangladesh. The physicochemical parameters of water were investigated for 3 points in the Turag River through experimental methods. The river water was black in color and the odor was bad which indicate that the water is polluted and dangerous for aquatic ecosystem and human health. The temperature of water was within an average value of $28.39^{\circ} \mathrm{C}$ which indicates standard temperature (20 to $\left.30^{\circ} \mathrm{C}\right)$ for aquatic medium. The average value of $\mathrm{pH}$ was 6.83 , which indicates that the value was within the standard limits $(6.5$ to 8.0$)$ for aquatic organisms. The values of DO water were within the range of 0.6 to $3.9 \mathrm{ppm}$ with an average value of $2.25 \mathrm{ppm}$ indicating low DO value from standard level (4.0 to $6.0 \mathrm{ppm}$ for domestic and $5.0 \mathrm{ppm}$ for fish culture). The values of BOD were within the average value of $1.15 \mathrm{ppm}$ indicating lower condition compared to standard value of BOD (6.0 ppm for fish culture and $10.0 \mathrm{ppm}$ for irrigation). The average value of TDS was $340.86 \mathrm{ppm}$ which indicates low TDS condition. The EC values were ranged from 35 to $150 \mu \mathrm{S} / \mathrm{cm}$ with an average value of $56.30 \mu \mathrm{S} / \mathrm{cm}$ which indicates lower condition than the standard value. The average value of transparency was $28.39 \mathrm{~cm}$. The average value of hardness was $106.79 \mathrm{ppm}$ which indicates near to the standard level. The average alkalinity was $237.66 \mathrm{ppm}$ indicating very lower condition than the standard limit (2000 ppm for irrigation). From this investigation, it is recommended that the water quality of the Turag River is beyond the acceptable limit. So, effective measures should be taken to reduce the level of pollution and mitigate the existing aquatic environmental problems of the Turag River.
\end{abstract}

Key Words: Turag River, Water pollution, Water quality

\section{Introduction}

Water is the most valuable and vital resource for sustenance of life and also for any developmental activity (Kumar et al., 2010). About $80 \%$ of the earth surface covered with water. Out of the estimated 1,011 million $\mathrm{km}^{3}$ of the total water present on the earth, only $33,400 \mathrm{~m}^{3}$ of water is available for drinking, agriculture, domestic and industrial consumption (Dara, 2007). Bangladesh is a low lying flat country with big inland water bodies, including some of the biggest rivers in the world and is extremely vulnerable because of its geographical characteristics (Matin and Kamal, 2010).

The increasing urbanization and industrialization of Bangladesh have negative implications for water quality where the industrial effluents directly discharge into the rivers without any consideration of the environment (BCAS, 2000). There has been a growing concern over the possible contamination of soils, sediments and water systems around many of the industrial areas of the countries (Chowdhury et al., 2007). Huge quantities of industrial effluents, solid waste from river-side settlements, petroleum products from ships, launches, cargoes, boats, untreated sewage etc. regularly get dumped into the Buriganga, Turag, Balu and Shitalakshya rivers, which are already severely polluted (Khan et al., 2007). The surface water along these peripheral rivers of Dhaka city is known to be highly polluted due to municipal and industrial untreated waste waters that are discharged into these rivers (Kamal et al., 1999; Karn and Harada, 2001).
The Turag River is the upper tributary of the Buriganga, a major river in Bangladesh. Both organic and inorganic waste effluents that are discharged into the Turag River water adversely interacting with the river system and deteriorating the water quality of the river. For this reason, water causes the adverse effect of surrounding land and aquatic ecosystem as well as subsequent impact on the livelihood of the local community (Meghla et al., 2013; Rahman et al., 2012). The major pollution sources of Turag River water are various consumer goods industries (soap and detergent), garments industries, pharmaceuticals industries, dyeing industries, aluminum industries, battery manufacturing, match industries, ink manufacturing industries, textile, paint, iron industries, pulp and paper factories, chemical factories, frozen food factories and steel workshop etc. (Rahman et al., 2012).

The Turag River has been declared as ecologically critical areas (ECA) by the Department of Environment. Study on Turag River water quality was carried out in different time by Department of Environment (DoE, 2001). But the various industries besides the Turag River are continuously discharging their effluents and waste water into the Turag River and seriously polluting the river water. As a result, the values of different physiochemical parameters are continuously changing at an alarming rate in this river water. The scientists all over the world are searching the causes of water pollution, sources of water pollution and trying to 
find out the ways to prevent the water pollution as well as environment from pollution. The study was conducted to know the existing status of different physiochemical parameters of the Turag River water. So it is very important to compile the available data and at the same time consider new data to understand current status and trend of water quality of the Turag River and their manifestation in the aquatic organisms and impacts on surrounding environment. Keeping all this views in mind, the study was performed to assess the current status of physicochemical parameters of the Turag River water and find out the protective measures to mitigate the pollution level of this river water.

\section{Materials and Methods}

Study Area

The Turag river is located at Tongi in Gazipur, Bangladesh. The entire regime of the Turag River is almost a semi-funnel shaped basin and its catchment is located on the central and southern part of Madhupur tract and flows from north to south within the basin and its length is 40 miles to the maximum (Uddin, 2005). The Turag River is the upper tributary of the Buriganga River. The river originates from the Bangshi River, the latter an important tributary of the Dhaleshwari River, flows through Gazipur and joins the Buriganga at Mirpur and the Tongi Khal links the Turag with the Balu River (Chowdhury and Chowdhury, 2004). The study area was divided into 3 points and 9 stations in which 3 stations are near Abdullahpur-

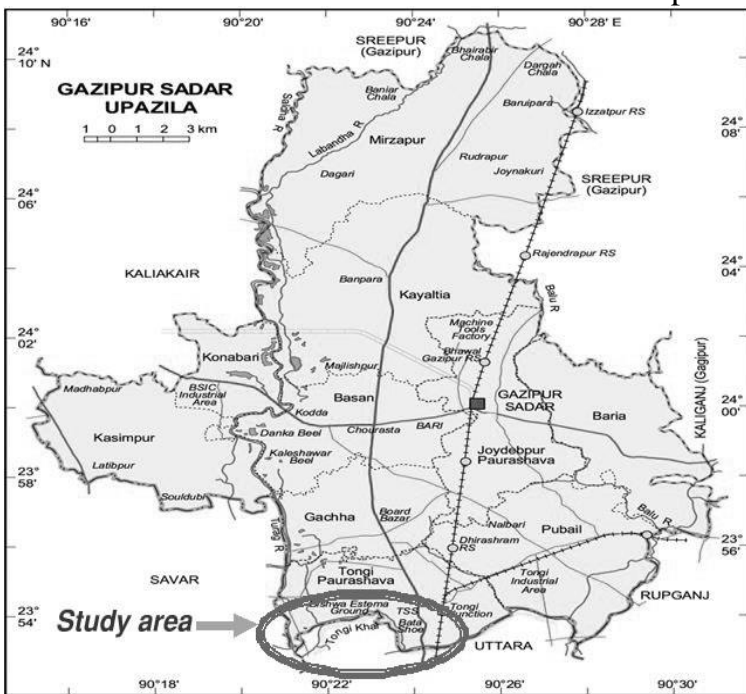

Fig. 1. The map showing the Study Area

(Source: Banglapedia, 2008).

\section{Materials used}

For the analysis of physicochemical properties of water different instruments such as $\mathrm{pH}$ meter, thermometer, secchi disk, DO meter, EC meter, TDS meter, measuring tape, bottles (black and white), burette, pipette, buffer solution, distilled water, concentrated $\mathrm{H}_{2} \mathrm{SO}_{4}, \mathrm{NaSO}_{4}$ etc. were used.
Tongi Bridge $\left(\mathrm{P}_{1}\right), 3$ are near Kamarpara Bridge (Bishwa Estema field) $\left(\mathrm{P}_{2}\right)$ and another 3 are near Ashulia Beribad Bridge $\left(\mathrm{P}_{3}\right)$. The study area is shown in Fig. 1 and Fig. 2.

\section{Sample collection and processing}

The water samples were collected for physicochemical analysis from three points such as $\mathrm{P}_{1}, \mathrm{P}_{2}$ and $\mathrm{P}_{3}$ as well as samples were collected from three stations from each point such as $S_{1}, S_{2}$, and $\mathrm{S}_{3}$. From each sampling station, $500 \mathrm{ml}$ of water samples were collected by plastic bottles. Temperature, DO and transparency values were measured at 9.00 am to $3.00 \mathrm{pm}$ in every 30 days interval from the study area. For analyzing the $\mathrm{pH}$, BOD, TDS, EC, alkalinity and hardness, the water samples were also collected from all points between 9.00 am to $3.00 \mathrm{pm}$ at every month interval from the study area. Before sampling, the bottles were cleaned and washed with detergent solution and rinsed again three times to avoid contamination. After sampling, alkaline potassium iodide solution was added to protect water samples from any fungal and other pathogenic attack. Sampling bottles were sealed immediately to avoid exposure to air and placed into safe place. The bottles were screwed carefully and marked with the respective identification number. Necessary information for each sample such as date of sample collection, time of sample collection, location etc., were recorded in the note book.

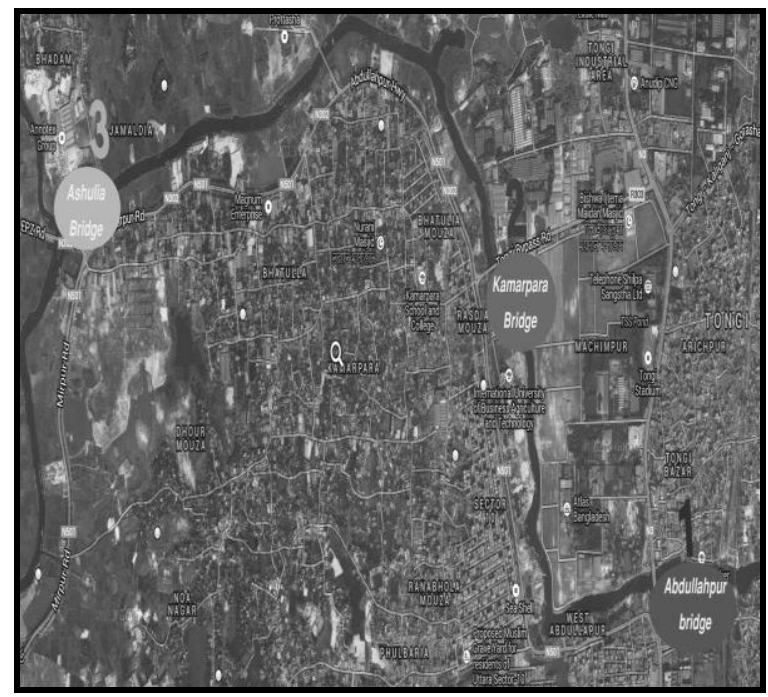

Fig. 2. Satellite image of the Turag River (Source: Google Earth).

\section{Sample analysis}

The study was conducted through experimental method. The samples were analyzed through experiment with the independent variable. The color was observed visually and the odor was felt with nose. The $\mathrm{pH}$, temperature, transparency, DO, EC and TDS were measured by $\mathrm{pH}$ meter (model$\mathrm{pH}$ Scan WP 1, 2, Malaysia), thermometer $\left({ }^{\circ} \mathrm{C}\right.$ 
scale), secchi disk, DO meter, EC meter (modelHM digital, Germany) and TDS meter respectively. Other parameters such as alkalinity and hardness were analyzed by using iodometric titration in the laboratory of the department of Environmental Science and Resource Management (ESRM) in

\section{Results and Discussions}

\section{Color and Odor}

Water samples collected from the Turag River were black in color and had foul odor that indicate Mawlana Bhashani Science \& Technology
University (MBSTU).

\section{Data processing and analysis}

The collected data were analyzed by using the software MS Excel. Some figures were edited by Adobe Photoshop CS 8.0.

polluted aquatic environment. This may due to the contamination by industrial effluents.

Table 1: Physical parameters of the Turag River water during the month April to July, 2013

\begin{tabular}{|c|c|c|c|c|c|c|c|c|}
\hline \multirow{2}{*}{ Parameters } & \multirow{2}{*}{$\begin{array}{c}\text { Locations } \\
\text { Points }\end{array}$} & \multicolumn{5}{|c|}{ Months } & \multirow{2}{*}{ Range } & \multirow{2}{*}{ Standard } \\
\hline & & April & May & June & July & Average & & \\
\hline \multirow{5}{*}{ 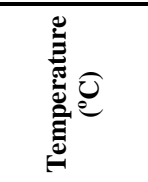 } & $\mathrm{P}_{1}$ & 27.66 & 28.67 & 23.33 & 30.67 & 27.58 & \multirow{5}{*}{$\begin{array}{c}23 \\
\text { to } \\
31^{\circ} \mathrm{C}\end{array}$} & \multirow{5}{*}{$\begin{array}{l}20 \text { to } 30{ }^{\circ} \mathrm{C} \\
(\mathrm{EQS}, 1997)\end{array}$} \\
\hline & $\mathrm{P}_{2}$ & 30.66 & 29 & 26.33 & 30 & 28.99 & & \\
\hline & $\mathrm{P}_{3}$ & 28.66 & 28.67 & 26.33 & 30.67 & 28.58 & & \\
\hline & Mean & & & & & 28.39 & & \\
\hline & SD & & & & & 0.73 & & \\
\hline \multirow{5}{*}{ 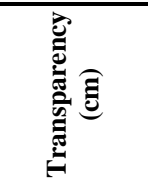 } & $\mathrm{P}_{1}$ & 12.3 & - & 38.5 & 34.33 & 28.38 & \multirow{5}{*}{$\begin{array}{c}9.5 \\
\text { to } \\
44 \mathrm{~cm}\end{array}$} & \multirow{5}{*}{$\begin{array}{c}40 \text { or less } \\
\text { (Rahman, 1992) }\end{array}$} \\
\hline & $\overline{\mathrm{P}_{2}}$ & 10.4 & - & 40 & 39 & 29.80 & & \\
\hline & $\mathrm{P}_{3}$ & 10 & - & 45.83 & 42 & 32.61 & & \\
\hline & Mean & & & & & 30.26 & & \\
\hline & SD & & & & & 2.15 & & \\
\hline \multirow{5}{*}{ 畐 } & $\mathrm{P}_{1}$ & 491.33 & 272 & 246 & 270.33 & 319.92 & \multirow{5}{*}{$\begin{array}{c}203 \\
\text { to } \\
902 \mathrm{ppm}\end{array}$} & \multirow{5}{*}{$\begin{array}{l}165 \text { (Huq and } \\
\text { Alam, 2005) }\end{array}$} \\
\hline & $\mathrm{P}_{2}$ & 461.33 & 226 & 216.67 & 263 & 291.75 & & \\
\hline & $\mathrm{P}_{3}$ & 885.67 & 303.33 & 214.33 & 240.33 & 410.92 & & \\
\hline & Mean & & & & & 340.86 & & \\
\hline & SD & & & & & 62.28 & & \\
\hline \multirow{5}{*}{ 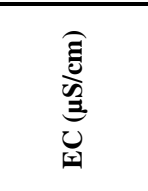 } & $\mathrm{P}_{1}$ & 78.33 & 45.33 & 41.67 & 44.33 & 52.42 & \multirow{5}{*}{$\begin{array}{c}35 \\
\text { to } \\
150 \mu \mathrm{S} / \mathrm{cm}\end{array}$} & \multirow[t]{5}{*}{70 (EQS, 1997) } \\
\hline & $\mathrm{P}_{2}$ & 73.33 & 38.67 & 37.33 & 44 & 48.33 & & \\
\hline & $\mathrm{P}_{3}$ & 145.33 & 51.33 & 36.33 & 39.67 & 68.17 & & \\
\hline & Mean & & & & & 56.30 & & \\
\hline & SD & & & & & 10.47 & & \\
\hline
\end{tabular}

\section{Temperature}

The temperature of all collected water samples from three locations were within the range of 23 to $31^{\circ} \mathrm{C}$ with an average value of $28.39^{\circ} \mathrm{C}(\mathrm{SD} \pm 0.73)$. The minimum temperature was found at Abdullahpur $\left(\mathrm{P}_{1}\right)$ in the month of June as $23.33^{\circ} \mathrm{C}$ and the maximum temperature was found at Abdullahpur $\left(\mathrm{P}_{1}\right)$ and Ashulia $\left(\mathrm{P}_{3}\right)$ in the month of July as $30.67^{\circ} \mathrm{C}$ (Table 1). In case of river water temperature, the DoE standard for sustaining aquatic life is 20 to $30{ }^{\circ} \mathrm{C}$ both in dry and wet season (Bhaumik et al., 2006). According to the observed values, the temperature in the Turag River water is within the range of DoE standard limit. All the samples in the study area were exceed DoE standard limit except during the month of July. Surface water temperature can be influenced by factors such as geographical position, seasonality, diurnal period, circulation of air, quantity of cloud cover, depth of water and its flow rate.

\section{Transparency}

The observed transparency values of water samples in the three sampling points were varied from 9.5 to $44 \mathrm{~cm}$ with an average value of $30.26 \mathrm{~cm}$ $(\mathrm{SD} \pm 2.15)$. In the month of May transparency was not analyzed. The minimum and maximum transparencies were found at Ashulia $\left(\mathrm{P}_{3}\right)$ in the month of April as $10 \mathrm{~cm}$ and in the month of July as $45.83 \mathrm{~cm}$ respectively (Table 1 ). The transparency of the fresh water is 35 to $45 \mathrm{~cm}$ is suitable for aquatic environment (Hossain et al., 2011). So, the transparency of water collected from the Turag River was within the acceptable range except in the month of because of dry seasons. During dry seasons dilution of effluent is low as a result transparency is low.

\section{Total Dissolved Solids (TDS)}

The TDS of all collected water samples from three locations were within the range of 203 to $902 \mathrm{ppm}$ with an average value of $340.86 \mathrm{ppm}(\mathrm{SD} \pm 62.28$ ). The minimum TDS was found as $214.33 \mathrm{ppm}$ at Ashulia $\left(\mathrm{P}_{3}\right)$ in the month of June and the maximum TDS was found as $885.67 \mathrm{ppm}$ in the month of April at Ashulia $\left(\mathrm{P}_{3}\right)$ (Table 1). The standard of TDS for domestic water supplies is $500 \mathrm{ppm}$ by USPH (De, 2005). The acceptable standard of TDS for drinking water is $1000 \mathrm{ppm}$, industrial water is $1500 \mathrm{ppm}$, livestock is $5000 \mathrm{ppm}$, and irrigation is 2000 ppm (ADB, 1994). A similer observation was reported by Meghla et al. (2013) for the assessment 
of physicochemical properties of water from Turag River in Dhaka City, Bangladesh. From the study it has been observed that the concentration of TDS was within the limit of standard (TDS $<1000 \mathrm{ppm}$ ) in the months of April to July. High TDS values indicate the presence of an appreciable quantities of bicarbonates, sulphates and chlorides of $\mathrm{Ca}, \mathrm{Mg}$ and $\mathrm{Na}$ (Karanth, 1994).

\section{Electrical Conductivity (EC)}

The EC of all collected water samples from three locations were within the range of 35 to $150 \mu \mathrm{S} / \mathrm{cm}$ with an average value of $56.30 \mu \mathrm{S} / \mathrm{cm}(\mathrm{SD} \pm 10.47)$. The minimum and maximum EC were found as $36.33 \mu \mathrm{S} / \mathrm{cm}$ at Ashulia $\left(\mathrm{P}_{3}\right)$ in the month of June and $145.33 \mu \mathrm{S} / \mathrm{cm}$ in the month of April respectively (Table 1). The standard of electrical conductivity is $1200 \mu \mathrm{S} / \mathrm{cm}$ for inland surface water (ECR, 1997). The acceptable range of EC for recreational water is $500 \mu \mathrm{S} / \mathrm{cm}$, irrigation is 750 $\mu \mathrm{S} / \mathrm{cm}$ and aquaculture is 800 to $1000 \mu \mathrm{S} / \mathrm{cm}$ (ADB, 1994). From the study, the measured EC of all water samples collected from the Turag River was lower than acceptable range. In the monsoon season, the flow of the river increases which may cause the dilution of the salinity of the water, while in dry season, the flow of the river decreases which results in increase of EC. The EC values of Turag River water were ranged from 691 to 822,618 to 1334 and 155 to $276 \mu \mathrm{S} / \mathrm{cm}$ in post monsoon, premonsoon and monsoon season respectively (Meghla et al., 2013).

Table 2: Chemical parameters of the Turag River water during the month April to July, 2013

\begin{tabular}{|c|c|c|c|c|c|c|c|c|}
\hline \multirow[b]{2}{*}{ Parameters } & \multirow{2}{*}{$\begin{array}{c}\text { Locations } \\
\text { Points }\end{array}$} & \multicolumn{5}{|c|}{ Months } & \multirow[b]{2}{*}{ Range } & \multirow[b]{2}{*}{ Standard } \\
\hline & & April & May & June & July & Average & & \\
\hline \multirow{5}{*}{ 플 } & $\mathrm{P}_{1}$ & 6.55 & 6.4 & 6.67 & 7.42 & 6.76 & \multirow{5}{*}{$\begin{array}{c}6.18 \\
\text { to } \\
7.46\end{array}$} & \multirow{5}{*}{$\begin{array}{c}6.5 \text { to } 8.5 \\
\text { (EQS, 1997; } \\
\text { Das, 1997) }\end{array}$} \\
\hline & $\mathrm{P}_{2}$ & 6.72 & 6.5 & 6.75 & 7.38 & 6.84 & & \\
\hline & $\mathrm{P}_{3}$ & 6.71 & 6.65 & 6.74 & 7.42 & 6.88 & & \\
\hline & Mean & & & & & 6.83 & & \\
\hline & SD & & & & & 0.06 & & \\
\hline \multirow{5}{*}{ 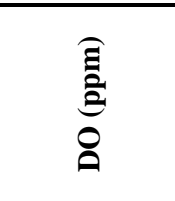 } & $\mathrm{P}_{1}$ & 1.2 & 1.1 & 1.6 & 2.97 & 1.72 & \multirow{5}{*}{$\begin{array}{c}0.6 \\
\text { to } \\
3.9 \mathrm{ppm}\end{array}$} & \multirow{5}{*}{$\begin{array}{c}4.0 \text { to } 6.0 \\
\text { ppm (De, } \\
\text { 2005), } 5 \mathrm{ppm} \\
\text { (Meade, } 1998)\end{array}$} \\
\hline & $\mathrm{P}_{2}$ & 1 & 2.23 & 2.47 & 3.3 & 2.25 & & \\
\hline & $\mathrm{P}_{3}$ & 1.2 & 2.97 & 3.13 & 3.77 & 2.77 & & \\
\hline & Mean & & & & & 2.25 & & \\
\hline & $\mathrm{SD}$ & & & & & 0.53 & & \\
\hline \multirow{5}{*}{ 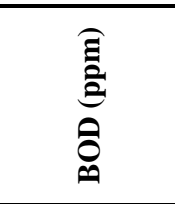 } & $\mathrm{P}_{1}$ & 1.17 & 0.7 & 1.07 & 1.67 & 1.15 & \multirow{5}{*}{$\begin{array}{c}0.4 \\
\text { to } \\
1.9 \mathrm{ppm}\end{array}$} & \multirow{5}{*}{$\begin{array}{c}6 \mathrm{ppm} \text { or less } \\
(\mathrm{ECR}, 1997)\end{array}$} \\
\hline & $\mathrm{P}_{2}$ & 0.47 & 0.63 & 1.57 & 1.43 & 1.03 & & \\
\hline & $\mathrm{P}_{3}$ & 0.6 & 0.93 & 1.97 & 1.63 & 1.28 & & \\
\hline & Mean & & & & & 1.15 & & \\
\hline & $\mathrm{SD}$ & & & & & 0.13 & & \\
\hline \multirow{5}{*}{ 咅高 } & $\mathrm{P}_{1}$ & 411.1 & 310.33 & 184.8 & 167.2 & 268.36 & \multirow{5}{*}{$\begin{array}{c}95.6 \\
\text { to } \\
417.6 \\
\text { ppm }\end{array}$} & \multirow{5}{*}{$\begin{array}{c}>100 \\
\text { (Rahaman, } \\
\text { 1992) }\end{array}$} \\
\hline & $\mathrm{P}_{2}$ & 354.53 & 261.9 & 171.23 & 140.43 & 232.02 & & \\
\hline & $\mathrm{P}_{3}$ & 354.53 & 239.13 & 147.4 & 109.3 & 212.59 & & \\
\hline & Mean & & & & & 237.66 & & \\
\hline & $\mathrm{SD}$ & & & & & 28.31 & & \\
\hline \multirow{5}{*}{ 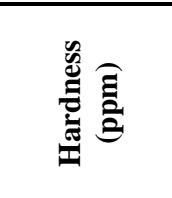 } & $\mathrm{P}_{1}$ & 212.53 & 151.27 & 80.83 & 63.73 & 127.09 & \multirow{5}{*}{$\begin{array}{c}36.9 \\
\text { to } \\
217.4 \\
\text { ppm }\end{array}$} & \multirow{5}{*}{$\begin{array}{c}123 \text { ppm } \\
\text { (Huq and } \\
\text { Alam, 2005) }\end{array}$} \\
\hline & $\mathrm{P}_{2}$ & 165.23 & 125.93 & 64.3 & 45.97 & 100.36 & & \\
\hline & $\mathrm{P}_{3}$ & 165.23 & 113.5 & 52.6 & 40.37 & 92.93 & & \\
\hline & Mean & & & & & 106.79 & & \\
\hline & SD & & & & & 17.97 & & \\
\hline
\end{tabular}

\section{pH}

The $\mathrm{pH}$ of all collected water samples from three locations were within the range of 6.18 to 7.46 with an average value of $6.83(\mathrm{SD} \pm 0.06)$. The minimum and maximum $\mathrm{pH}$ values were found as 6.4 at Abdullahpur $\left(\mathrm{P}_{1}\right)$ in the month of April and 7.42 in the month of July respectively (Table 2). The acceptable range of $\mathrm{pH}$ for irrigation water is 6.5 to 8.5 according to Bangladesh standards, FAO standards and Bangladesh Environment Conservation Rule (ADB, 1994; ECR, 1997). The acceptable range of $\mathrm{pH}$ for fish culture is 6.5 to 8.0 (Meade, 1998; ADB, 1994; ECR, 1997). The acceptable range of $\mathrm{pH}$ for drinking water is 6.5 to
8.5 , recreational water is 6.0 to 9.5 , industrial water is 6.0 to 9.5 and livestock water is 5.5 to 9.0 (ADB, 1994). The $\mathrm{pH}$ standard limits for inland surface water is 6.5 to 8.5 (EQS, 1997). The study found that the $\mathrm{pH}$ values of all sampling sites were within the standard limit.

\section{Dissolved Oxygen (DO)}

The DO of all collected water samples from three locations were within the range of 0.6 to $3.9 \mathrm{ppm}$ with an average value of $2.25(\mathrm{SD} \pm 0.53)$. The minimum DO was found as $1.0 \mathrm{ppm}$ at Kamarpara $\left(\mathrm{P}_{2}\right)$ in the month of April and maximum DO was found as $3.77 \mathrm{ppm}$ at Ashulia $\left(\mathrm{P}_{3}\right)$ in the month of July (Table 2). In the case of dissolved oxygen, 
standard for sustaining aquatic life is $5 \mathrm{ppm}$, where as drinking water a purpose is $6 \mathrm{mg} / \mathrm{l}$ (Alam et al., 2007). The acceptable range of DO for domestic water supplies is 4.0 to $6.0 \mathrm{ppm}$ by United State Public Health (USPH) standard and 3.0 ppm (ISI) standard (De, 2005). The standard range of DO for fish culture is 5 ppm to saturation (Meade, 1998) and more than $5.0 \mathrm{ppm}$ (Chowdhury, 2007). The optimum DO in natural water is 4.0 to $6.0 \mathrm{ppm}$ (De, 2005). According to the environmental quality standard (EQS), the following requirements for DO are prescribed: $6.0 \mathrm{ppm}$ for drinking, 4.0 to $5.0 \mathrm{ppm}$ for recreation, 4.0 to $6.0 \mathrm{ppm}$ for fish and livestock and $5.0 \mathrm{ppm}$ for industrial application (Rahaman et al., 2012). On the basis of the study, the measured values of DO of all water samples collected from Turag River water were not within the acceptable range. Adequate dissolved oxygen is necessary for good water quality. Oxygen is a necessary element to all forms of life. As dissolved oxygen levels in water drop below $5.0 \mathrm{ppm}$, aquatic life is put under stress. Accumulation of huge amount of industrial effluents from Tongi industrial area and dumping of solid wastes into the Turag River water are the main reasons for lower DO value.

\section{Biochemical Oxygen Demand (BOD)}

The BOD of all collected water sample from three locations were within range of 0.4 to $1.9 \mathrm{ppm}$ with an average value of $1.15 \mathrm{ppm}(\mathrm{SD} \pm 0.13)$. The minimum BOD was found as $0.47 \mathrm{ppm}$ at Kamarpara $\left(\mathrm{P}_{2}\right)$ in the month of April and maximum BOD was found as $1.97 \mathrm{ppm}$ at Ashulia $\left(\mathrm{P}_{3}\right)$ in the month of June (Table 2). The permissible limit for BOD for drinking water is $0.2 \mathrm{ppm}$, recreational water is $3 \mathrm{ppm}$, fish culture is $6 \mathrm{ppm}$ and irrigation is $10 \mathrm{ppm}$ in Bangladesh standard (ECR, 1997). The biochemical oxygen demand value was higher in the month of July and in
Ashulia sampling point for less water pollution and rain water flow in this area. Lower BOD value was found in the month of April and May in Kamarpara sampling site due to accumulation of various industrial effluents in the Tongi industrial area.

\section{Hardness}

The hardness of all collected water samples from three locations were within the range of 36.9 to $217.4 \mathrm{ppm}$ with an average value of 106.79 $(\mathrm{SD} \pm 17.97)$. The minimum hardness was found as $40.37 \mathrm{ppm}$ at Ashulia $\left(\mathrm{P}_{3}\right)$ in the month of July and the maximum as $151.27 \mathrm{ppm}$ at Abdullahpur $\left(\mathrm{P}_{1}\right)$ in the month of April (Table 2). According to the Department of Environment (DoE) standard permissible limit of hardness of drinking water is 200 to $500 \mathrm{ppm}$ (ECR, 1997). According to Huq and Alam (2005), the hardness standard is $123 \mathrm{ppm}$. On the basis of total hardness, water can be classified as soft $(<75 \mathrm{ppm})$, moderately hard (75$150 \mathrm{ppm})$, hard (150-300 ppm) and very hard (>300 ppm) (Sawyer and McCarty, 1967). According to these criteria, water samples were graded as moderately hard in all points. But in the month of June and July water was soft.

\section{Alkalinity}

The alkalinity of all collected water samples from three locations were varied from 95.6 to $417.6 \mathrm{ppm}$ with an average value of $237.66(\mathrm{SD} \pm 28.31$ ) (Table 2). The minimum alkalinity was found as 109.98 ppm at Ashulia $\left(\mathrm{P}_{3}\right)$ in the month of July and maximum alkalinity was found as $411.10 \mathrm{ppm}$ at Abdullahpur $\left(\mathrm{P}_{1}\right)$ in the month of April (Table 2). According to Rahman (1992), standard value of alkalinity is $>100 \mathrm{ppm}$. On the basis of alkalinity most of the water samples was within the standard limit.

\section{Correlation between Different Properties of Water}

Table 3. Correlation matrix table of water quality parameters

\begin{tabular}{|c|c|c|c|c|c|c|c|c|}
\hline Parameters & $\begin{array}{l}\text { Transpare } \\
\text { ncy }(\mathbf{c m})\end{array}$ & $\begin{array}{l}\text { TDS } \\
(\mathbf{p p m})\end{array}$ & pH & $\begin{array}{l}\text { DO } \\
\text { (ppm) }\end{array}$ & $\begin{array}{l}\mathrm{EC} \\
(\mu \mathrm{S} / \mathrm{cm})\end{array}$ & $\begin{array}{l}\text { BOD } \\
\text { (ppm) }\end{array}$ & $\begin{array}{l}\text { Hardness } \\
\text { (ppm) }\end{array}$ & $\begin{array}{l}\text { Alkalinity } \\
\text { (ppm) }\end{array}$ \\
\hline $\begin{array}{l}\text { Temperature } \\
\left({ }^{\circ} \mathrm{C}\right)\end{array}$ & $-0.326^{\mathrm{NS}}$ & $0.267^{\mathrm{NS}}$ & $0.506^{\mathrm{NS}}$ & $0.181^{\mathrm{NS}}$ & $0.257^{\mathrm{NS}}$ & $-0.231^{\mathrm{NS}}$ & $0.157^{\mathrm{NS}}$ & $0.151^{\mathrm{NS}}$ \\
\hline $\begin{array}{l}\text { Transparency } \\
\text { (cm) }\end{array}$ & & $-0.999 * *$ & $0.485^{\mathrm{NS}}$ & $0.863^{*}$ & $-0.999 * *$ & $0.991 * *$ & $-0.979 * *$ & $-0.979 * *$ \\
\hline TDS (ppm) & & & $-0.271^{\mathrm{NS}}$ & $-0.804 *$ & $0.999 * *$ & $\begin{array}{c}-0.625 \\
\text { NS }\end{array}$ & $0.844^{*}$ & $0.870^{*}$ \\
\hline pH & & & & $0.787 *$ & $-0.286^{\mathrm{NS}}$ & $0.715^{\mathrm{NS}}$ & $-0.671^{\mathrm{NS}}$ & $-0.651^{\mathrm{NS}}$ \\
\hline DO (ppm) & & & & & $-0.813 *$ & $0.809^{*}$ & $-0.936 * *$ & $-0.943 * *$ \\
\hline $\mathrm{EC}(\mu \mathrm{S} / \mathrm{cm})$ & & & & & & $\begin{array}{c}-0.633 \\
\text { NS }\end{array}$ & $0.851^{*}$ & $0.877 * *$ \\
\hline BOD (ppm) & & & & & & & $-0.936^{* *}$ & $-0.916 * *$ \\
\hline $\begin{array}{l}\text { Hardness } \\
\text { (ppm) }\end{array}$ & & & & & & & & $0.998 * *$ \\
\hline
\end{tabular}

Legend: $* *=$ Significant at $1 \%$ level; $*=$ Significant at $5 \%$ level; ${ }^{\mathrm{NS}}=$ Not Significant; tabulated values of $\mathrm{r}$ with df is 0.875 at $1 \%$ level of significant and 0.754 at $5 \%$ level of significant. 
The study showed that the parameters are linearly correlated to a large extent. Table 3 is showing the correlation matrix of water sample, which shows positive correlation between transparency and DO $\left(\mathrm{r}=0.863^{*}\right)$; transparency and BOD $\left(\mathrm{r}=0.991^{* * *}\right)$; TDS and EC $\left(\mathrm{r}=0.999^{* *}\right)$; TDS and hardness $\left(\mathrm{r}=0.844^{*}\right)$; TDS and alkalinity $\left(\mathrm{r}=0.870^{*}\right) ; \mathrm{pH}$ and DO $\left(\mathrm{r}=0.787^{*}\right)$; DO and BOD $\left(\mathrm{r}=0.809^{*}\right)$; EC and hardness $\left(0.851^{*}\right)$; EC and alkalinity $\left(0.877^{* *}\right)$ hardness and alkalinity $\left(\mathrm{r}=0.998^{* * *}\right)$. Similarly, some negative correlations are shown between transparency and TDS ( $\left.\mathrm{r}=-0.999^{* *}\right)$; transparency and EC $\left(\mathrm{r}=-0.999^{* *}\right)$; transparency and hardness $(\mathrm{r}=-$ $\left.0.999^{* *}\right)$; transparency and alkalinity $\left(\mathrm{r}=-0.979^{* *}\right)$; TDS and DO $\left(\mathrm{r}=-0.804^{* *}\right)$; DO and EC ( $\mathrm{r}=-$ $\left.0.813^{*}\right)$; DO and alkalinity $\left(\mathrm{r}=-0.943^{* *}\right)$; BOD and hardness $\left(\mathrm{r}=-0.936^{* *}\right) ; \quad \mathrm{BOD}$ and alkalinity $\left(\mathrm{r}=0.916^{* *}\right)$.

\section{Conclusions and Recommendations}

Bangladesh is a small, under developed and riverine country with several important rivers which provides a wide range of potentiality for economic development. This study was conducted to assess the physicochemical parameters of the Turag River water. The examined physicochemical parameters indicate that the water quality of Turag River is unsuitable for aquatic lives. These parameters help us in selecting the right options to manage water resources and also assess water quality of Turag River properly. The present study shows that the color of Turag River water was deep black in color and the odor was bad smell which means the water is polluted and dangerous for aquatic ecosystem and human health. The temperatures of all water samples collected from three locations were with an average value of $28.39{ }^{\circ} \mathrm{C}$ indicating near to the standard temperature $\left(20\right.$ to $\left.30^{\circ} \mathrm{C}\right)$ for aquatic medium. The average value of $\mathrm{pH}$ was 6.83 which is within the standard limit (6.5 to 8.0) for aquatic organisms. The values of DO at different sampling points of the Turag River water were within the range of 0.6 to $3.9 \mathrm{ppm}$ with an average value of $2.25 \mathrm{ppm}$ indicating low DO value from standard level (4.0 to $6.0 \mathrm{ppm}$ for domestic and $5.0 \mathrm{ppm}$ for

\section{References}

ADB (Asian Development Bank). 1994. Training $\begin{array}{llr}\text { Manual for } & \text { Environmental } \\ \text { Monitoring. Engineering } & \text { Science } \\ \text { Incorporation, USA, 2-26. } & \end{array}$

Alam, M. J. B.; Muyen, Z.; Islam, M. R.; Islam, S. and Mamun, M. 2007. "Water quality parameters along river." International Journal of Environmental Science and Technology, 4(1):159-167.

Banglapedia. 2008. National Encyclopedia of Bangladesh. Asiatic Society of Bangladesh. fish culture), which is not suitable for aquatic body. The BOD of all collected water samples from all locations were within the average value of 1.15 ppm indicating low value compared to standard value $(6.0 \mathrm{ppm}$ for fish culture and $10.0 \mathrm{ppm}$ for irrigation). The average values of TDS was 340.86 ppm which indicates low TDS value. The EC values recorded at different sampling points of the Turag River water were ranged from 35 to 150 $\mu \mathrm{S} / \mathrm{cm}$ with an average value of $56.30 \mu \mathrm{S} / \mathrm{cm}$ which is very low compared to standard value (800 to $1000 \mu \mathrm{S} / \mathrm{cm}$ for aquaculture and $750 \mu \mathrm{S} / \mathrm{cm}$ for irrigation). The average value of transparency of all water samples from each sampling points was 28.39 $\mathrm{cm}$ which indicates low transparency for aquatic environment. The average value of hardness of all collected water sample were $106.79 \mathrm{ppm}$ indicating near to standard level (123 ppm). The average alkalinity of all collected water samples from all locations was $237.66 \mathrm{ppm}$ indicating very lower condition than the standard limit (2000 ppm for irrigation). However, it may be concluded from the above results that the water quality of the Turag River is beyond acceptable limit that is unfavorable for all aquatic lives and human beings due to discharging of untreated industrial effluents into the Turag River water without considering aquatic lives existing in the river water. So, effective measures should be taken to reduce the level of pollution and mitigate the existing aquatic environmental problems of the Turag River water. Every industry should have an effluent treatment plant (ETP) and low cost water treatment process should be developed and its implementation should be mandatory by the Government which may change the present situation. Social awareness about the consequences of environmental degradation is to be created by the government through mass media such as TV, radio newspapers and other media.

\section{Acknowledgement}

The authors acknowledge all of officials and laboratory staffs of the Department of ESRM, MBSTU, Tangail for their best co-operation and laboratory supports during the research work.

BCAS (Bangladesh Center for Advance Studies). 2000. Pollution Study. Management of Aquatic Ecosystem through Community Husbandry (MACH), Dhaka, Bangladesh.

Bhaumika, U.; Das, P. and Paria, T. 2006. Impact of Plankton Structure on Primary Production in Two Beels of West, India. Bangladesh Journal of Fisheries Research, 10(1):1-11.

Chowdhury, A. G. and Chowdhury, A. 2004. An assessment of water resources and flood 
management of Dhaka city. Water resources management and development in Dhaka city, Geothe-institute, Dhaka, Bangladesh, 40-45.

Chowdhury, A. M. S.; Rahman, M. A.; Rahman, M. M.; Mohiuddin, A. S. M. and Zaman, M. B. 2007. Nature and the extent of industrial pollution in river water around Dhaka city. Bangladesh Journal of Environmental Science, 13(1):46-49.

Dara, S. S. 2007. A Textbook of Environmental Chemistry and Pollution Control. $7^{\text {th }}$ ed. S. Chand and Company Ltd., Ram Nagar, New Delhi, India, pp.44-75.

De, A. K. 2005. Environmental Chemistry. $5^{\text {th }}$ ed. New Age International (P) Ltd., Daryagang, New Delhi, India, 187.

DoE (Department of Environment). 2001. The general over view of pollution status of river of Bangladesh. Government of the People's Republic of Bangladesh, Ministry of Environment and Forest, Department of Environment, Dhaka, Bangladesh.

ECR (Environmental Conservation Rules). 1997. Government of the People's Republic of Bangladesh. Ministry of Environment and Forest, Department of Environment, Dhaka, Bangladesh, pp: 212-214.

EQS (Environmental Quality Standard). 1997. Government of the People's Republic of Bangladesh. Ministry of Environment and Forest, Department of Environment, Gazette, registered nr. DA-1, Dhaka, Bangladesh.

Hossain M. U.; Farzana, S. and Mia, M. Y. 2011. Assessment of Aquatic Environmental Parameters in the Louhajang River, Tangail, Bangladesh. Journal of Science and Technology, 1(1): 65-71.

Huq, S. M. I. and Alam, M. D. 2005. A Handbook on Analysis of Soil, Plant and Water. BACER-DU, University of Dhaka, Bangladesh.

Kamal, M. M.; Hansen, A. M. and Badruzzaman A. B. M. 1999. Assessment of pollution of the River Buriganga, Bangladesh, using a water quality model. Water Science and Technology. 40(2):129-136.

Karanth, K. R. 1994. Ground Water Assessment Development and Management. Tata McGraw-Hill Publishing Company Ltd, New Delhi, India. Pp: 248-250.
Karn, S. K. and Harada, H. 2001. Surface water pollution in three urban territories of Nepal, India, and Bangladesh. Environmental Management, 28(4): 438496.

Khan, M. A. I.; Hossain, A. M.; Huda, M. E.; Islam M. S. and Elahi, S. F. 2007. Physicochemical and biological aspects of monsoon waters of Ashulia for economic and aesthetic applications: preliminary studies. Bangladesh Journal of Science and Industry Res. 42(4): 377396.

Kumar, G. N. P.; Srinivas, P.; Chandra, G. K. and Sujatha, P. 2010. Delineation of groundwater potential zones using remote sensing and GIS techniques: A case study of Kurmapalli Vagu Basin in Andhra Pradesh, India. International Journal of Water Resources and Environmental Engineering, 2(3):70-78.

Matin, M. A. and Kamal, R. 2010. Impact of climate change on river system. In The International Symposium on Environmental Degradation and Sustainable Development (ISEDSD), Dhaka, Bangladesh, pp. 61-65.

Meade, J. W. 1998. Aquaculture Management. CBS Publishers \& Distributors, New Delhi, India, 9p.

Meghla, N. T.; Islam, M. S.; Ali, M. A.; Suravi and Sultana, N. 2013. Assessment of Physicochemical Properties of Water from the Turag River in Dhaka City, Bangladesh. International Journal of Current Microbiology Applied Science, 2(5):110-122.

Rahman, M. S. 1992. Water quality management in aquaculture. BRAC Prokashana, Bangladesh, 84p.

Rahman, A. K. M. L.; Islam, M.; Hossain, M. Z. and Ahsan, M. A. 2012. Study of the seasonal variations in Turag river water quality parameters. African Journal of Pure and Applied Chememistry, 6(10): 144-148.

Sawyer, C. N. and McCarty, P. L. 1967. Chemistry for Sanitary Engineers. $2^{\text {nd }}$ ed. McGraw Hill, New York, USA, 518p.

Uddin, H. M. 2005. Initial environmental impact assessment of the Turag-Buriganga naval transport. M.Sc. dissertation (unpublished), Department of Geography and Environment, Jahangirnagar University, Dhaka. 